\title{
Platinum(II) complexes with carbazates and hydrazides: Synthesis, spectral characterization, computational modeling, and biological studies
}

\author{
M.A. Rodrigues ${ }^{\text {a }}$, I.M. Marzano ${ }^{b}$, G.H. Ribeiro ${ }^{c}$, L. Colina-Vegas ${ }^{c}$, M. Pivatto ${ }^{\text {a }}$, A.P.S. Fontes ${ }^{\mathrm{d}}$, \\ C.M. Ribeiro ${ }^{\text {e }}$, F.R. Pavan ${ }^{\mathrm{e}}$, K.J. de Almeida ${ }^{\mathrm{f}}$, A.A. Batista ${ }^{\text {C }}$, E.C. Pereira-Maia ${ }^{\mathrm{b}}$, W. Guerra ${ }^{\mathrm{a}, *}$ \\ a Instituto de Química, Universidade Federal de Uberlândia, Campus Santa Mônica, 38400-902 Uberlândia, MG, Brazil \\ ${ }^{\mathrm{b}}$ Departamento de Química, Universidade Federal de Minas Gerais, Campus Pampulha, 31270-901 Belo Horizonte, MG, Brazil \\ ${ }^{\mathrm{c}}$ Departamento de Química, Universidade Federal de São Carlos, 13565-905 São Carlos, SP, Brazil \\ ${ }^{\mathrm{d}}$ Departamento de Química, Universidade Federal de Juiz de Fora, 36036-900 Juiz de Fora, MG, Brazil \\ e Faculdade de Ciências Farmacêuticas, Departamento de Ciências Biológicas, Universidade Estadual Paulista, Campus Araraquara, 14801-902 Araraquara, SP, Brazil \\ ${ }^{\mathrm{f}}$ Departamento de Química, Universidade de Federal de Lavras, 37200-000 Lavras, MG, Brazil
}

\section{A R T I C L E I N F O}

\section{Article history:}

Received 14 March 2015

Accepted 15 June 2015

Available online 20 June 2015

\section{Keywords:}

Platinum complexes

Hydrazide

Carbazate

Computational modeling

Cytotoxic activity

\begin{abstract}
A B S T R A C T
This work reports on the synthesis and characterization of complexes of the type cis- $\left[\mathrm{Pt}(\mathrm{L})_{2} \mathrm{X}_{2}\right]$, where $\mathrm{L}=4$-methoxybenzylcarbazate (4-MC), benzyl carbazate (BC), 4-fluorophenoxyacetic acid hydrazide (4$\mathrm{FH}), 3$-methoxybenzoic acid hydrazide (3-MH), ethyl carbazate (EC), tert-butyl carbazate (TC), (4hydroxy-phenyl)-acetic acid hydrazide $(4-\mathrm{HH})$, and $\mathrm{X}^{-\mathrm{Cl}^{-}}$or $\mathrm{I}^{-}$. The structures of the platinum(II) complexes were optimized and theoretical data show good agreement with the experimental results, suggesting that the ligands are coordinated via the $\mathrm{NH}_{2}$ groups. The cytotoxic activity of three representative compounds was evaluated in a chronic myelogenous leukemia cell line and health cell line from mouse (L929). The platinum complex with 4-fluorophenoxyacetic acid hydrazide was more active than the free ligand and carboplatin therefore it may be considered a promising antitumor agent. In addition, the platinum complexes with 4-methoxybenzylcarbazate (4-MC) and benzyl carbazate (BC) exhibited good activity. On the other hand, microbiological assays against Mycobacterium tuberculosis showed that all complexes and organic compounds are not very active.
\end{abstract}

(c) 2015 Elsevier Ltd. All rights reserved.

\section{Introduction}

Isoniazid, also known as isonicotinic acid hydrazide (or INH), is an organic compound that is the first-line medication in prevention and treatment of Mycobacterium tuberculosis H37Rv. Thus, hydrazides ( $\left.\mathrm{R}-\mathrm{CO}-\mathrm{NH}-\mathrm{NH}_{2}\right)$, in general, are of interest due to their biological activities, such as, antibacterial, antifungical, and antitumoral activities [1-3]. This class of compounds, and their analogues have the ability to readily coordinate to a variety of transition metals. In addition, it is known that one way to improve the biological activity of organic compounds is complexing them to a transition metal [1-6], therefore, many hydrazides complexes have been synthesized and characterized [7-9]. Some of these metallic complexes also exhibit interesting biological properties,

* Corresponding author at: Instituto de Química, Universidade Federal de Uberlândia, Av. João Naves de Ávila, 2121, Campus Santa Mônica, 38400-902, Uberlândia, MG, Brazil. Tel.: +55 343239 4143; fax: +55 3432394208.

E-mail address: wg@iqufu.ufu.br (W. Guerra). including antitumoral, anti-mycobacterial and antibacterial activities [10-17]. For instance, the effect of ternary complexes of copper(II) with 2-furoic acid hydrazide or 2-thiophenecarboxylic acid hydrazide on the growth of tumoral cells was studied in a leukemia cell line. These complexes were able to enter cells and inhibit cellular growth in a concentration-dependent manner, with an activity higher than that of the corresponding free ligands [14]. Our research group also showed that platinum(II) complexes containing 4-nitrobenzoic hydrazide exhibit strong growth inhibitory effect in leukemia cells in vitro. For example, the compound cis$\left[\mathrm{Pt}(4-\mathrm{NH})_{2} \mathrm{I}_{2}\right]$ inhibits the growth of $\mathrm{K} 562$ cells with an $\mathrm{IC}_{50}$ value equal to $0.96 \mu \mathrm{M}$, and is 10 -fold more active in vitro than carboplatin, for the same cell [15].

Several carbazates ( $\mathrm{R}-\mathrm{O}-\mathrm{CO}-\mathrm{NH}-\mathrm{NH}_{2}$ ) have been synthesized and their properties have been reported in the literature [18-19]. Surprisingly, the studies on their metal complexes appear to be scarce, although some reports are available. For instance, a cobalt(III) complex with the condensation derivative of 2-(diphenylphosphino)benzaldehyde and ethyl carbazate was 
synthesized by Milenković et al. The cobalt(III) complex showed a very high cytotoxic activity, which was approximately twofold higher than cisplatin on cervix (HeLa), and melanoma tumor cell lines (FemX), and almost threefold higher in colorectal tumor cell line (LS-174) [20].

To extend our investigation on hydrazides and their metallic compounds, this paper reports on the synthesis, characterization and biological studies of new platinum(II) complexes with 4methoxybenzylcarbazate (4-MC), benzyl carbazate (BC), 4-fluorophenoxyacetic acid hydrazide (4-FH), 3-methoxybenzoic acid hydrazide (3-MH), ethyl carbazate (EC), tert-butyl carbazate (TC) and (4-hydroxy-phenyl)-acetic acid hydrazide (4-HH). Regarding the pharmacological importance of metal-based drugs, this work is, as much as is from our knowledge, the first to describe biological properties of platinum(II) complexes with carbazates and 4fluorophenoxyacetic acid hydrazide.

\section{Experimental}

\subsection{Physical measurements}

Conductivity studies were carried out with a Tecnopon mCA-150 conductivity meter using a cell of constant $1.03 \mathrm{~cm}^{-1}$, spectroscopic grade dimethyl sulfoxide (Merck) $\left(\Lambda_{\mathrm{M}}=0.99 \mu \mathrm{s} / \mathrm{cm}\right)$ and tetraethylammonium bromide $\left(\Lambda_{\mathrm{M}}=79.02 \mu \mathrm{s} / \mathrm{cm}\right)$ were used as a standard compounds. Elemental analyses of the synthesized complexes were performed with a model 2400 Perkin Elmer elemental analyzer. Thermogravimetric analyses (TG/DTA) were obtained on a TGA-50 Shimadzu, using $8.0 \mathrm{mg}$ samples packed in aluminum crucible. Samples were heated at $10^{\circ} \mathrm{C} / \mathrm{min}$ from room temperature to $600^{\circ} \mathrm{C}$, in a dynamic nitrogen atmosphere (flow rate of $200 \mathrm{~mL} / \mathrm{min})$. IR spectra were registered in $\mathrm{KBr}\left(4000-400 \mathrm{~cm}^{-1}\right)$ or CSI $\left(400-200 \mathrm{~cm}^{-1}\right)$ pellets on a FTIR spectrometer BomemMichelson spectrometer. High-resolution ElectroSpray Ionization Mass Spectrometry (HRESIMS) were measured on an ultrOTOF (Bruker Daltonics) spectrometer, operating in the positive mode. Methanol was used as solvent system and the samples were infused into the ESI source at a flow rate of $5 \mu \mathrm{L} / \mathrm{min}$. The calculated values for the charged complex ions were made using ChemDraw Ultra 12.0. ${ }^{1} \mathrm{H}$ NMR (400 MHz) and ${ }^{195} \mathrm{Pt}$ NMR (64 MHz) spectra were recorded on a Bruker spectrometer and were obtained by dissolving the complexes in DMSO- $d_{6}$. The chemical shifts were expressed as $\delta$ (in $\mathrm{ppm}$ ) from internal reference standard TMS $\left({ }^{1} \mathrm{H}\right.$ NMR) and $\mathrm{K}_{2} \mathrm{PtCl}_{6}$ ( $\left.{ }^{195} \mathrm{Pt} \mathrm{NMR}\right)$.

\subsection{Starting materials}

The reagents (ligands and metal salts) are commercially available (Sigma-Aldrich). All other chemicals reagents were of analytical grade, purchased from different sources, and used without prior purification.

\subsection{Preparation of the complexes}

The compounds IV and VIII were prepared according to procedures described in the literature $[16,17]$. The others complexes were synthesized following the procedures described below:

(a) cis-[Pt $\left.(\mathrm{L})_{2} \mathrm{Cl}_{2}\right]$ complexes: To a solution of $\mathrm{K}_{2} \mathrm{PtCl}_{4}(0.2075 \mathrm{~g}$, $0.5 \mathrm{mmol})$ in water $(5 \mathrm{~mL}), 5.0 \mathrm{~mL}$ of a methanolic solution of hydrazide or carbazate $(1.0 \mathrm{mmol})$ was added. The mixture was stirred for $36 \mathrm{~h}$ and the solid formed was separated by filtration, washed with water, methanol and dried under reduced pressure. (b) cis- $\left[\mathrm{Pt}(\mathrm{L})_{2} \mathrm{I}_{2}\right]$ complexes: To a solution of $\mathrm{K}_{2} \mathrm{PtCl}_{4}(0.2075 \mathrm{~g}$, $0.5 \mathrm{mmol}$ ) in water $(5 \mathrm{~mL})$ an excess of potassium iodide in water $(2.0 \mathrm{mmol})$ was added. After stirring for $20 \mathrm{~min}$ to ensure formation of $\mathrm{K}_{2} \mathrm{PtI}_{4}$, the appropriate ligand ( $1 \mathrm{mmol}$ ) dissolved in methanol $(5 \mathrm{~mL})$ was added. After $24 \mathrm{~h}$ at room temperature, the solid formed was filtered off, washed with water, methanol and dried under reduced pressure.

\subsubsection{Complex I or [Pt(4-MC) $\left.\mathbf{C l}_{2}\right]$}

Yield: 82\%. Color: Yellow. Molar weight $\left(\mathrm{g} \mathrm{mol}^{-1}\right)$ : 658.38. Anal. Calc. for $\left[\mathrm{Pt}\left(\mathrm{C}_{9} \mathrm{H}_{12} \mathrm{~N}_{2} \mathrm{O}_{3}\right)_{2} \mathrm{Cl}_{2}\right]$ : $\mathrm{C}, 32.84 ; \mathrm{H}, 3.68 ; \mathrm{N}, 8.51$. Found: $\mathrm{C}$, $32.35 ; \mathrm{H}, 3.42 ; \mathrm{N}, 8.43 \% .{ }^{1} \mathrm{H}$ NMR (400 MHz; DMSO- $\left.d_{6}\right) \delta(\mathrm{ppm})$ : 8.93, 7.53, 7.32, 7.30, 5.02, 3.75. ${ }^{195} \mathrm{Pt}$ NMR (64 MHz; DMSO-d 6 ) $\delta$ (ppm): -2253. IR spectra in $\mathrm{KBr}, v\left(\mathrm{~cm}^{-1}\right)$ : 3267, 3219, 3180, 3074, 2958, 2836, 1690, 1614, 1596, 1534, 1517, 1458, 1303, 1256, 1178, 1131, 1114, 1031, 951, 918, 862, 824, 805, 761, 720, $574,557,533 . \Lambda_{M}=6.55 \mu \mathrm{s} / \mathrm{cm}$.

\subsubsection{Complex II or $\left[\mathbf{P t}(\mathbf{B C})_{2} \mathbf{C l}_{2}\right]$}

Yield: 95\%. Color: Yellow. Molar weight $\left(\mathrm{g} \mathrm{mol}^{-1}\right)$ : 598.34. Anal. Calc. for $\left[\mathrm{Pt}\left(\mathrm{C}_{8} \mathrm{H}_{10} \mathrm{~N}_{2} \mathrm{O}_{2}\right)_{2} \mathrm{Cl}_{2}\right]$ : C, 32.12; $\mathrm{H}, 3.38 ; \mathrm{N}, 9.36$. Found: $\mathrm{C}$, 32.49; $\mathrm{H}, 3.67 ; \mathrm{N}, 9.44 \%$. HRESIMS $(\mathrm{MeOH}) \mathrm{m} / z$ 563.0806 [M-Cl] $]^{+}$ (calcd. for $\left.\left[\mathrm{Pt}\left(\mathrm{C}_{8} \mathrm{H}_{10} \mathrm{~N}_{2} \mathrm{O}_{2}\right)_{2} \mathrm{Cl}\right], 563.0822\right) .{ }^{1} \mathrm{H}$ NMR $(400 \mathrm{MHz}$; DMSO-d $\left._{6}\right) \delta(\mathrm{ppm}): 8.27,7.57,7.35,5.04$. IR spectra in $\mathrm{KBr}$, $v\left(\mathrm{~cm}^{-1}\right): 3277,3213,3184,3130,3091,3033,2959,1734,1728$, 1693, 1620, 1606, 1563, 1531, 1494, 1455, 1383, 1335, 1297, 1251, 1135, 1026, 980, 939, 774, 754, 727, 694, 602, 575, 536, 457. $\Lambda_{\mathrm{M}}=3.87 \mu \mathrm{s} / \mathrm{cm}$.

\subsubsection{Complex III or [Pt(4-FH) $\left.\mathbf{C l}_{2}\right]$}

Yield: 98\%. Color: Yellow. Molar weight $\left(\mathrm{g} \mathrm{mol}^{-1}\right)$ : 634.32. Anal. Calc. for $\left[\mathrm{Pt}\left(\mathrm{C}_{8} \mathrm{H}_{9} \mathrm{FN}_{2} \mathrm{O}_{2}\right)_{2} \mathrm{Cl}_{2}\right]$ : C, 30.29; $\mathrm{H}, 2.87 ; \mathrm{N}, 8.83$. Found: $\mathrm{C}$, 30.19; $\mathrm{H}, 2.55 ; \mathrm{N}, 8.68 \%$. HRESIMS $(\mathrm{MeOH}) \mathrm{m} / \mathrm{z} 599.0626[\mathrm{M}-\mathrm{Cl}]^{+}$ (calcd. for $\left.\left[\mathrm{Pt}\left(\mathrm{C}_{8} \mathrm{H}_{9} \mathrm{FN}_{2} \mathrm{O}_{2}\right)_{2} \mathrm{Cl}\right], 599.0634\right) .{ }^{1} \mathrm{H}$ NMR $(400 \mathrm{MHz}$; DMSO-d $\left.d_{6}\right) \delta(\mathrm{ppm}): 9.36,8.00,7.12,6.98,4.59 .{ }^{195} \mathrm{Pt}$ NMR $\left(64 \mathrm{MHz}\right.$; DMSO-d $\left.\mathrm{d}_{6}\right) \delta(\mathrm{ppm}):-2247$. IR spectra in $\mathrm{KBr}, v\left(\mathrm{~cm}^{-1}\right)$ : 3334, 3159, 3096, 2978, 2918, 1702, 1685, 1601, 1507, 1439, $1420,1332,1300,1251,1220,1207,1155,1100,1072,826,776$, 513, 412. $\Lambda_{\mathrm{M}}=9.77 \mu \mathrm{s} / \mathrm{cm}$.

\subsubsection{Complex IV or [Pt(3-MH)Cl $\left.\mathbf{C l}_{2}\right]$}

Yield: 75\%. Color: Yellow. Molar weight $\left(\mathrm{g} \mathrm{mol}^{-1}\right)$ : 597.98. Anal. Calc. for $\left[\mathrm{Pt}\left(\mathrm{C}_{8} \mathrm{H}_{10} \mathrm{~N}_{2} \mathrm{O}_{2}\right)_{2} \mathrm{Cl}_{2}\right]$ : C, 32.13; $\mathrm{H}, 3.38 ; \mathrm{N}, 9.36$. Found: $\mathrm{C}$, 32.05; $\mathrm{H}, 3.25 ; \mathrm{N}, 9.17 \%$. HRESIMS $(\mathrm{MeOH}) \mathrm{m} / z 563.0820[\mathrm{M}-\mathrm{Cl}]^{+}$ (calcd for $\left.\left[\mathrm{Pt}\left(\mathrm{C}_{8} \mathrm{H}_{10} \mathrm{~N}_{2} \mathrm{O}_{2}\right)_{2} \mathrm{Cl}\right], 563.0822\right) .{ }^{195} \mathrm{Pt} \mathrm{NMR}(64 \mathrm{MHz}$; DMSO- $\left.d_{6}\right) \delta(\mathrm{ppm}):-2212$. IR spectra in $\mathrm{KBr}, v\left(\mathrm{~cm}^{-1}\right)$ : 3273 , 3193, 3166, 3072, 3001, 2970, 2943, 2835, 1668, 1602, 1580, $1525,1487,1466,1431,1313,1282,1250,1222,1185,1129$, 1045, 1031, 995, 935, 868, 824, 792, 742, 678, 552, 486. $\Lambda_{\mathrm{M}}=13.63 \mu \mathrm{s} / \mathrm{cm}$.

\subsubsection{Complex $\boldsymbol{V}$ or $\left[\boldsymbol{P t}(\mathbf{4}-\mathbf{M C})_{2} \mathbf{I}_{\mathbf{2}}\right]$}

Yield: 97\%. Color: Yellow. Molar weight $\left(\mathrm{g} \mathrm{mol}^{-1}\right)$ : 841.28. Anal. Calc. for $\left[\mathrm{Pt}\left(\mathrm{C}_{9} \mathrm{H}_{12} \mathrm{~N}_{2} \mathrm{O}_{3}\right)_{2} \mathrm{I}_{2}\right]$ : C, 25.70; $\mathrm{H}, 2.88 ; \mathrm{N}, 6.66$. Found: C, 25.58; H, 2.84; N, 6.53\%. ${ }^{195} \mathrm{Pt}$ NMR (64 MHz; DMSO- $\left.d_{6}\right) \delta(\mathrm{ppm})$ : -3230 . IR spectra in $\mathrm{KBr}, v\left(\mathrm{~cm}^{-1}\right): 3276,3235,3192,3148,3117$, 3077, 3000, 2981, 2934, 2834, 1691, 1613, 1575, 1517, 1462, 1423, 1377, 1338, 1318, 1295, 1251, 1176, 1134, 1111, 1027, $950,924,900,860,820,760,731,600,576,529,520,450$. $\Lambda_{\mathrm{M}}=10.03 \mu \mathrm{s} / \mathrm{cm}$.

\subsubsection{Complex VI or $\left[\mathbf{P t}(\mathbf{B C})_{2} \mathbf{I}_{2}\right]$}

Yield: 58\%. Color: Brown. Molar weight $\left(\mathrm{g} \mathrm{mol}^{-1}\right)$ : 781.24. Anal. Calc. for $\left[\mathrm{Pt}\left(\mathrm{C}_{8} \mathrm{H}_{10} \mathrm{~N}_{2} \mathrm{O}_{2}\right)_{2} \mathrm{I}_{2}\right]$ : C, 24.60; $\mathrm{H}, 2.59 ; \mathrm{N}, 7.17$. Found: C, 24.30; H, 2.70; N, 7.00\%. HRESIMS (MeOH) $m / z 654.0197[\mathrm{M}-\mathrm{I}]^{+}$ (calcd. for $\left.\left[\mathrm{Pt}\left(\mathrm{C}_{8} \mathrm{H}_{10} \mathrm{~N}_{2} \mathrm{O}_{2}\right){ }_{2} \mathrm{I}\right], 654.0177\right) .{ }^{195} \mathrm{Pt} \mathrm{NMR}(64 \mathrm{MHz}$; 
DMSO- $\left.d_{6}\right) \delta(\mathrm{ppm}):-3198$. IR spectra in $\mathrm{KBr}, v\left(\mathrm{~cm}^{-1}\right)$ : 3265, 3189, 3169, 3118, 3034, 1690, 1657, 1576, 1525, 1465, 1452, 1384, 1298, 1276, 1251, 1215, 1134, 1079, 962, 912, 846, 750, 698, 574, 534, 514, 457. UV-Vis (acetonitrile), $\lambda_{\max }(\mathrm{nm})$ 206, 225, 245, 280. $\Lambda_{\mathrm{M}}=9.86 \mu \mathrm{s} / \mathrm{cm}$.

\subsubsection{Complex VII or [Pt(4-FH) $\left.)_{2} \boldsymbol{I}_{2}\right]$}

Yield: 90\%. Color: Orange. Molar weight $\left(\mathrm{g} \mathrm{mol}^{-1}\right)$ : 817.22. Anal. Calc. for $\left[\mathrm{Pt}\left(\mathrm{C}_{8} \mathrm{H}_{9} \mathrm{FN}_{2} \mathrm{O}_{2}\right)_{2} \mathrm{I}_{2}\right]$ : C, 23.51; $\mathrm{H}, 2.22 ; \mathrm{N}, 6.85$. Found: $\mathrm{C}$, 23.24; $\mathrm{H}, 2.32 ; \mathrm{N}, 6.59 \%$. HRESIMS $(\mathrm{MeOH}) \mathrm{m} / z 690.0020[\mathrm{M}-\mathrm{I}]^{+}$ (calcd. for $\left.\left[\mathrm{Pt}\left(\mathrm{C}_{8} \mathrm{H}_{9} \mathrm{FN}_{2} \mathrm{O}_{2}\right)_{2} \mathrm{I}\right], 689.9989\right) .{ }^{195} \mathrm{Pt} \mathrm{NMR}(64 \mathrm{MHz}$; DMSO $\left.-d_{6}\right) \delta(\mathrm{ppm}):-3263$. IR spectra in $\mathrm{KBr}, v\left(\mathrm{~cm}^{-1}\right)$ : 3301 , $3148,3090,3048,2918,1704,1674,1573,1503,1439,1425$, $1384,1364,1342,1314,1298,1252,1219,1209,1153,1099$, 1074, 1006, 973, 860, 826, 795, 776, 725, 564, 515. $\Lambda_{\mathrm{M}}=27.81 \mu \mathrm{s} / \mathrm{cm}$.

\subsubsection{Complex VIII or [Pt(3-MH) $\left.)_{2} \mathbf{I}_{2}\right]$}

Yield: 95\%. Color: Pale green. Molar weight $\left(\mathrm{g} \mathrm{mol}^{-1}\right)$ : 780.88 . Anal. Calc. for $\left[\mathrm{Pt}\left(\mathrm{C}_{8} \mathrm{H}_{10} \mathrm{~N}_{2} \mathrm{O}_{2}\right)_{2} \mathrm{I}_{2}\right]$ : C, 24.61; H, 2.59; N, 7.17. Found: C, 24.69; $\mathrm{H}, 2.10 ; \mathrm{N}, 7.10 \%$. HRESIMS $(\mathrm{MeOH}) \mathrm{m} / \mathrm{z}$ $654.0200[\mathrm{M}-\mathrm{I}]^{+}$(calcd. for $\left.\left[\mathrm{Pt}\left(\mathrm{C}_{8} \mathrm{H}_{10} \mathrm{~N}_{2} \mathrm{O}_{2}\right)_{2} \mathrm{I}\right], 654.0177\right) .{ }^{195} \mathrm{Pt}$ NMR $\left(64 \mathrm{MHz}\right.$; DMSO- $\left.d_{6}\right) \delta(\mathrm{ppm}):-3171$. IR spectra in $\mathrm{KBr}$, $v\left(\mathrm{~cm}^{-1}\right)$ : 3228, 3209, 3198, 3180, 3146, 3069, 3001, 2964, 2831, $1643,1610,1573,1545,1504,1483,1449,1432,1324,1313$, 1298, 1251, 1234, 1123, 1046, 1027, 934, 888, 873, 816, 792, $751,724,688,522 . \Lambda_{\mathrm{M}}=24.52 \mu \mathrm{s} / \mathrm{cm}$.

\subsubsection{Complex $\mathbf{I X}$ or $\left[\boldsymbol{P t}(\boldsymbol{E C})_{2} \boldsymbol{I}_{2}\right]$}

Yield: 96\%. Color: Gray. Molar weight $\left(\mathrm{g} \mathrm{mol}^{-1}\right)$ : 657.10. Anal. Calc. for $\left[\mathrm{Pt}\left(\mathrm{C}_{3} \mathrm{H}_{8} \mathrm{~N}_{2} \mathrm{O}_{2}\right)_{2} \mathrm{I}_{2}\right]$ : C, 10.97; $\mathrm{H}, 2.46 ; \mathrm{N}, 8.52$. Found: $\mathrm{C}$, $10.79 ; \mathrm{H}, 2.41 ; \mathrm{N}, 8.27 \%$. HRESIMS $(\mathrm{MeOH}) \mathrm{m} / z 529.9874[\mathrm{M}-\mathrm{I}]^{+}$ (calcd. for $\left.\left[\mathrm{Pt}\left(\mathrm{C}_{3} \mathrm{H}_{8} \mathrm{~N}_{2} \mathrm{O}_{2}\right)_{2} \mathrm{I}\right], 529.9864\right)$. IR spectra in $\mathrm{KBr}$, $v\left(\mathrm{~cm}^{-1}\right)$ : 3292, 3186, 3158, 1690, 1572, 1525, 1481, 1367, 1286, $1136,1030,881,795,766,727,551,544,513 . \Lambda_{M}=17.08 \mu \mathrm{s} / \mathrm{cm}$.

\subsubsection{Complex $\boldsymbol{X}$ or $\left[\boldsymbol{P t}(\mathbf{T C})_{2} \boldsymbol{I}_{2}\right]$}

Yield: 89\%. Color: Brown. Molar weight ( $\left.\mathrm{g} \mathrm{mol}^{-1}\right)$ : 713.20. Anal. Calc. for $\left[\mathrm{Pt}\left(\mathrm{C}_{5} \mathrm{H}_{12} \mathrm{~N}_{2} \mathrm{O}_{2}\right)_{2} \mathrm{I}_{2}\right]: \mathrm{C}, 16.84 ; \mathrm{H}, 3.40 ; \mathrm{N}, 7.85 \%$. Found: $\mathrm{C}$, $16.91 ; \mathrm{H}, 3.62 ; \mathrm{N}, 7.77 ; \%$. HRESIMS $(\mathrm{MeOH}) \mathrm{m} / z$ 586.0510 [M-I] ${ }^{+}$ (calcd. for $\left.\left[\mathrm{Pt}\left(\mathrm{C}_{5} \mathrm{H}_{12} \mathrm{~N}_{2} \mathrm{O}_{2}\right)_{2} \mathrm{I}\right], 586.0490\right)$. IR spectra in $\mathrm{KBr}$, $v\left(\mathrm{~cm}^{-1}\right): 3301,3244,3150,3111,2982,1703,1574,1496,1458$, 1449, 1390, 1365, 1308, 1252, 1157, 1120, 1014, 859, 804, 769, $757,735,603,434 . \Lambda_{\mathrm{M}}=14.43 \mu \mathrm{s} / \mathrm{cm}$.

\subsubsection{Complex $\mathbf{X I}$ or $\left[\mathbf{P t}(\mathbf{4}-\mathbf{H H})_{2} \mathbf{I}_{2}\right] \cdot 2.5 \mathrm{H}_{2} \mathrm{O}$}

Yield: $32 \%$. Color: Yellow. Molar weight $\left(\mathrm{g} \mathrm{mol}^{-1}\right)$ : 826.29. Anal. Calc. for $\left[\mathrm{Pt}\left(\mathrm{C}_{8} \mathrm{H}_{10} \mathrm{~N}_{2} \mathrm{O}_{2}\right)_{2} \mathrm{I}_{2}\right] \cdot 2.5 \mathrm{H}_{2} \mathrm{O}: \mathrm{C}, 23.26 ; \mathrm{H}, 3.05 ; \mathrm{N}, 6.08 \%$. Found: $\mathrm{C}, 22.70 ; \mathrm{H}, 3.40 ; \mathrm{N}, 6.51 \%$. HRESIMS $(\mathrm{MeOH}) \mathrm{m} / \mathrm{z}$ $654.0199[\mathrm{M}-\mathrm{I}]^{+}$(calcd. for $\left.\left[\mathrm{Pt}\left(\mathrm{C}_{8} \mathrm{H}_{10} \mathrm{~N}_{2} \mathrm{O}_{2}\right)_{2} \mathrm{I}\right], 654.0177\right)$. IR spectra in $\mathrm{KBr}, v\left(\mathrm{~cm}^{-1}\right): 3273,3167,3065,3044,1655,1614,1600$, $1582,1536,1515,1447,1364,1247,1226,1188,1174,1105$, 1060, 984, 941, 839, 797, 742, 594, 552, 524, 430. $\Lambda_{\mathrm{M}}=29.36 \mu \mathrm{s} / \mathrm{cm}$.

\section{Computational details}

Geometry optimization and vibrational frequency calculations were performed using Density Functional Theory level together with the hybrid B3IYP functional $[21,22]$. The Stuttgart/Dresden effective-core potential and associated basis set were used for platinum, which is abbreviated as SDD [23]. The standard 6-311G(d,p) basis sets were employed for the other atoms [24]. The solvent effects were included by means of PCM method. No symmetry restrictions have been imposed during the geometry optimizations. The GEDIIS algorithm [25] was employed throughout; the final structures were obtained with tight SCF and geometry convergence criteria in combination with the ultrafine integration grid. Frequency calculations were performed to confirm the nature of each stationary point, which also afforded zero-point energy (ZPE) corrections. The GAUSSIAN 09 program packet was used for these calculations. The relativistic effects were considered using Gamess-UK software by using the single-point calculations.

\subsection{Anti-M. tuberculosis activity assay}

The anti-MTB activity of the compounds was determined by the REMA (Resazurin Microtiter Assay) method according to Palomino et al. [26]. Stock solutions of the tested compounds were prepared in dimethyl sulfoxide (DMSO) and diluted in Middlebrook 7H9 broth (Difco) supplemented with oleic acid, albumin, dextrose and catalase (OADC enrichment - BBL/Becton-Dickinson), to obtain final drug concentration ranges of $0.09-25 \mu \mathrm{g} / \mathrm{mL}$. A serial dilution was performed on the equipment Precision ${ }^{\mathrm{TM}} \mathrm{XS}$ (Biotek). The rifampicin was dissolved in distilled water, and used as a standard drug. A suspension of the MTB H37Rv ATCC 27294 was cultured in Middlebrook 7H9 broth supplemented with OADC and $0.05 \%$ Tween 80 . The culture was frozen at $-80^{\circ} \mathrm{C}$ in aliquots. After two days was carried out the $\mathrm{CFU} / \mathrm{mL}$ of an aliquot. The concentration was adjusted by $5 \times 10^{5} \mathrm{UFC} / \mathrm{mL}$ and $100 \mu \mathrm{L}$ of the inoculum was added to each well of a 96 -well microtiter plate together $100 \mu \mathrm{L}$ the compounds. Samples were set up in triplicate. The plate was incubated for 7 days at $37^{\circ} \mathrm{C}$. After $24 \mathrm{~h} 30 \mu \mathrm{L}$ of $0.01 \%$ resazurin (solubilized in water) was added. The fluorescence of the wells was read after $24 \mathrm{~h}$ by TECAN Spectrafluor ${ }^{\circledR}$. The MIC was defined as the lowest concentration resulting in 90\% inhibition of growth of MTB.

\subsection{Cells and culture}

The K562 cell line was purchased from the Rio de Janeiro Cell Bank (number CR083 of the RJCB collection). This cell line was established from pleural effusion of a 53 year-old female with chronic myelogenous leukemia in terminal blast crisis. Cytotoxic activity also was investigated against non-tumor cell (L929), health cell line from mouse. All Cells were cultured in RPMI 1640 (Sigma Chemical Co.) medium supplemented with $10 \%$ fetal calf serum (CULTILAB, São Paulo, Brazil) at $37{ }^{\circ} \mathrm{C}$ in a humidified $5 \% \mathrm{CO}_{2}$ atmosphere. Cultures grow exponentially from $10^{5}$ cells $\mathrm{mL}^{-1}$ to about $8 \times 10^{5}$ cells $\mathrm{mL}^{-1}$ in three days. Cell viability was checked by Trypan Blue exclusion. The cell number was determined by Coulter counter analysis.

For cytotoxicity assessment, $1 \times 10^{5}$ cells $\mathrm{mL}^{-1}$ were cultured for $72 \mathrm{~h}$ in the absence and presence of a range of concentrations of tested compounds. The sensitivity to compound was evaluated by the concentration that inhibits cell growth by $50 \%, \mathrm{IC}_{50}$. Stock solutions were prepared in DMSO and diluted accordingly to obtain the concentrations used in the cytotoxic assays. The final concentration of dimethylsulfoxide in the culture medium was inferior to $0.1 \%$ and we have checked that the solvent has no effect on cell growth at this concentration.

\section{Results and Discussion}

In this work several complexes containing hydrazides and carbazates as ligands were synthesized and characterized by elemental analyses, conductivity measurements, FT-IR, High-resolution Electrospray Ionization Mass Spectrometry (HRESIMS) and RMN $\left({ }^{1} \mathrm{H}\right.$ and $\left.{ }^{195} \mathrm{Pt}\right)$. The complexes were synthesized by the slow 
A)<smiles>NNC(=O)COc1ccc(F)cc1</smiles>

4-FH<smiles>NNC(=O)Cc1ccc(O)cc1</smiles>
4-HH<smiles>NNC(=O)OCc1ccccc1</smiles>

$\mathrm{BC}$<smiles>COc1cccc(C(=O)NN)c1</smiles><smiles>COc1ccc(COC(=O)NN)cc1</smiles>

4-MC<smiles>CCOC(=O)NN</smiles>

EC<smiles>CC(C)(C)OC(=O)NN</smiles>

TC

B)

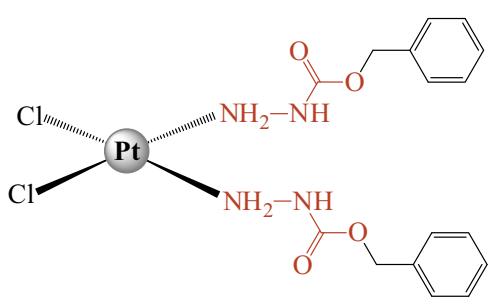

Fig. 1. (A) Ligands used in this study. (B) Proposed Structure of complex cis$\left[\mathrm{Pt}(\mathrm{BC})_{2} \mathrm{Cl}_{2}\right]$.

addition of the ligand to $\mathrm{K}_{2} \mathrm{PtCl}_{4}$ or $\mathrm{K}_{2} \mathrm{PtI}_{4}$, previously dissolved in water. After $24 \mathrm{~h}$, the resulting compounds were isolated by simple filtration. For the ligands (4-hydroxy-phenyl)-acetic acid hydrazide (4-HH), ethyl carbazate (EC) and tert-butyl carbazate (TC), the reaction using potassium tetrachloroplatinate(II) as a starting material did not produce the desired complexes under the previously employed experimental conditions. Therefore, they were synthesized using only the tetraiodoplatinate(II) salt. The complexes are colorful solids, non hygroscopic, stable to air and light, soluble in organic solvents such as DMSO and DMF and insoluble in $\mathrm{CHCl}_{3}, \mathrm{CH}_{2} \mathrm{Cl}_{2}$ and $\mathrm{CCl}_{4}$. In all reactions, the ligands have shown monodentate behavior forming complexes of general formula cis$\left[\mathrm{Pt}(\mathrm{L})_{2} \mathrm{Cl}_{2}\right]$. The chemical structures of the ligands and of the complex $\left[\mathbf{P t}(\mathbf{B C})_{2} \mathbf{C l}_{2}\right]$ are presented in Fig. 1.

The results of the elemental analyses are in accordance with the proposed structures. Presence of hydration water in the complex XI is confirmed by TG/DTA curves. Thus, weight loss events in the range of $45-100^{\circ} \mathrm{C}$ are due to the loss of 2.5 water molecules (Calculated: 5.44\%, Experimental: 5.61\%). The molar conductivity values of solutions $\left(10^{-3} \mathrm{M}\right.$; DMSO) for all complexes were far below that of the 1:1 standard electrolyte indicating that they are not charged [27].

\subsection{IR spectra}

To study the binding mode of hydrazides and carbazates to the platinum(II) ions, the IR spectra of the free ligands were performed for comparison to their corresponding complexes (see Table 1). For all ligands, characteristic absorptions in the 3330 to $3060 \mathrm{~cm}^{-1}$ region were observed, corresponding to $v \mathrm{NH}$ and vibrational frequencies between 1709 and $1639 \mathrm{~cm}^{-1}$ are due to $\mathrm{C}=0$ group. In the IR spectra of the complexes, the absorption corresponding to $v \mathrm{C}=\mathrm{O}$ of the carbonyl appears almost in the same wavenumber of the free ligand, therefore, we ruled out an involvement of this group in the coordination to the metallic ion. On the other hand, all the complexes showed considerable shift in bands originating from amino $\mathrm{NH}$ stretching frequency as compared to free ligands [28]. In addition, in the IR spectra of the complexes, a new peak assigned to $v(\mathrm{M}-\mathrm{N})$ appeared at $\approx 541 \mathrm{~cm}^{-1}$, indicating formation of the Pt-N bond. For the complexes containing chloride, two new absorptions in the region of 325 and $335 \mathrm{~cm}^{-1}$ may be assigned to $v \mathrm{M}-\mathrm{Cl}$ stretching in accordance to the cis geometry. Absorptions corresponding to $v \mathrm{Pt}-\mathrm{I}$ appear at $\approx 193$ and $185 \mathrm{~cm}^{-1}$ [29].

\subsection{Mass spectrometry}

The High-resolution ElectroSpray Ionization Mass Spectrometry (HRESIMS) of the synthesized complexes were recorded and the obtained data are according with the proposed structures. In this

Table 1

IR Spectral data for the ligands and their platinum complexes.

\begin{tabular}{|c|c|c|c|c|}
\hline Compound & $v\left(\mathrm{NH}_{2}\right), v(\mathrm{NH})$ & $v(\mathrm{C}=\mathrm{O})$ & $v(\mathrm{Pt}-\mathrm{N})$ & $v(\mathrm{Pt}-\mathrm{X})$ \\
\hline 4-MC & $3330 m^{a}, 3305 w, 3217 w, 3204 w$ & $1686 s$ & - & - \\
\hline I & $3267 \mathrm{~m}, 3219 w, 3180 w$ & $1690 s$ & $574 w$ & $341 w, 334 w$ \\
\hline $\mathbf{V}$ & $3276 w, 3235 w, 3192 w$ & $1691 \mathrm{~s}$ & $576 w$ & - \\
\hline $\mathrm{BC}$ & $3331 \mathrm{~m}, 3292 \mathrm{~m}, 3212 \mathrm{w}, 3187 \mathrm{w}$ & $1688 \mathrm{~s}$ & - & - \\
\hline II & $3277 \mathrm{~m}, 3213 \mathrm{~m}, 3184 \mathrm{w}, 3130 \mathrm{w}$ & $1693 \mathrm{~s}$ & $536 w$ & $335 w, 330 w$ \\
\hline VI & $3265 \mathrm{~m}, 3189 w, 3118 w$ & $1690 s$ & $514 w$ & - \\
\hline 4-FH & $3312 w, 3209 w, 3058 w$ & $1666 s$ & - & - \\
\hline III & $3334 w, 3159 w, 3096 w$ & $1702 s$ & $513 w$ & $332 w, 323 w$ \\
\hline VII & $3301 w, 3148 w, 3090 w$ & $1704 \mathrm{~s}$ & $564 w$ & - \\
\hline 3-MH & 3304sh, 3291m, 3208w & 1639s & - & - \\
\hline IV & $3273 m, 3193 m, 3166 w$ & $1668 \mathrm{~m}$ & $552 w$ & $338 w, 327 w$ \\
\hline VIII & 3228w, 3209sh, 3180w & $1643 s$ & $522 w$ & $193^{*} \mathrm{w}, 185^{*} \mathrm{w}$ \\
\hline $\mathrm{EC}$ & $3319 m, 3232 w, 3165 w$ & 1709s & - & - \\
\hline IX & $3292 \mathrm{~m}, 3186 w, 3158 w$ & $1690 s$ & $551 w$ & $322 w, 315 w$ \\
\hline TC & $3378 s, 3326 w, 3209 w$ & $1694 \mathrm{~s}$ & - & - \\
\hline $\mathbf{X}$ & $3301 \mathrm{~m}, 3244 w, 3150 w, 3111 w$ & $1703 s$ & - & - \\
\hline $4-\mathrm{HH}$ & $3325 \mathrm{~m}, 3308 \mathrm{~m}, 3273 \mathrm{sh}, 3197 \mathrm{w}$ & 1649s & - & - \\
\hline $\mathbf{X I}$ & $3273 w, 3167 w, 3065 w$ & $1655 s$ & $552 \mathrm{w}$ & - \\
\hline
\end{tabular}

abbreviations: s, strong; m, medium; w, weak; sh, shoulder.

"Value from [14]. 


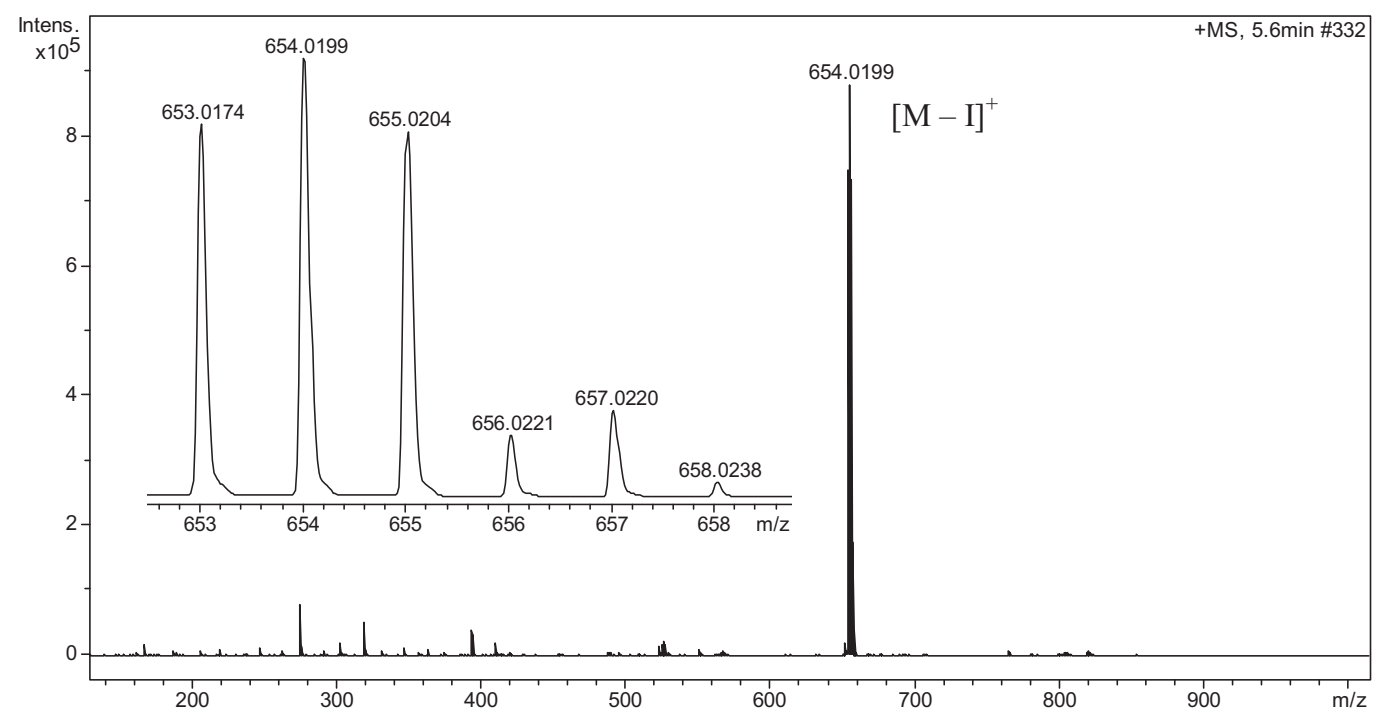

Fig. 2. HRESIMS spectrum of complex cis-[Pt(BC) $\left.)_{2} \mathbf{I}_{\mathbf{2}}\right]$. The charged complex ion observed was $[\mathrm{M}-\mathrm{I}]^{+}$.

Table 2

${ }^{1} \mathrm{H}$ NMR spectral data $\left(\delta\right.$, ppm) for DMSO- $d_{6}$ solutions of the ligands and complexes.

\begin{tabular}{llllll}
\hline Compound & $\mathrm{NH}_{2}$ & $\mathrm{NH}$ & $\mathrm{H}_{\mathrm{ar}}$ & $\mathrm{CH}_{2}$ & $\mathrm{CH}_{3}$ \\
\hline $4-\mathrm{MC}$ & $4.06 \mathrm{~s}$ & $8.18 \mathrm{~s}$ & $7.29-7.27 \mathrm{~m}$ & $4.95 \mathrm{~s}$ & $3.75 \mathrm{~s}$ \\
{$\left[\mathbf{P t}\left(\mathbf{4}-\mathbf{M C}_{2} \mathbf{C l}_{2}\right]\right.$ or $\mathbf{I}$} & $7.53 \mathrm{~s}$ & $8.93 \mathrm{~s}$ & $7.32-7.30 \mathrm{~m}$ & $5.02 \mathrm{~s}$ & $3.75 \mathrm{~s}$ \\
$\mathrm{BC}$ & $4.08 \mathrm{~s}$ & $8.27 \mathrm{~s}$ & $7.34 \mathrm{~m}$ & $5.04 \mathrm{~s}$ & - \\
{$\left[\mathbf{P t}(\mathbf{B C})_{2} \mathbf{C l}_{2}\right]$ or $\mathbf{I I}$} & $7.57 \mathrm{~s}$ & $9.02 \mathrm{~s}$ & $7.37 \mathrm{~m}$ & $5.10 \mathrm{~s}$ & - \\
$4-\mathrm{FH}$ & $4.32 \mathrm{~s}$ & $9.36 \mathrm{~s}$ & $6.98-7.12 \mathrm{~m}$ & $4.46 \mathrm{~s}$ & - \\
{$\left[\mathbf{P t}(4-\mathbf{F H})_{\mathbf{2}} \mathbf{C l}_{\mathbf{2}}\right]$ or III } & $8.00 \mathrm{~s}$ & $10.08 \mathrm{~s}$ & $6.98-7.12 \mathrm{~m}$ & $4.59 \mathrm{~s}$ & - \\
\hline
\end{tabular}

Abbreviations: s, singlet; m, multiplet.

work, the $m / z$ values listed in the text refer to the peak containing the most abundant isotope $\left({ }^{195} \mathrm{Pt}\right)$. As example, the mass spectrum obtained by electrospray ionization from a methanolic solution of $\left[\mathrm{Pt}(4-\mathrm{HH})_{2} \mathrm{I}_{2}\right]$ is given in Fig. 2. The peak at $m / z 654.0199$ was consistent with the loss of iodide $[\mathrm{M}-\mathrm{I}]^{+}$(calcd. for $\left[\mathrm{Pt}(4-\mathrm{HH})_{2} \mathrm{I}\right]^{+}$, 654.0177). The high-resolution mass spectra for all platinum complexes contained predominantly the species $[\mathrm{M}-\mathrm{I}]^{+}$or $[\mathrm{M}-\mathrm{Cl}]^{+}$.

\section{3. ${ }^{1} \mathrm{H}$ and ${ }^{195} \mathrm{Pt}$ NMR spectra}

The ${ }^{1} \mathrm{H}$ NMR spectra of the complexes (I-III) containing chloride were recorded in DMSO- $d_{6}$ (Table 2). In the spectra of the free ligands, the signal corresponding to the $\mathrm{NH}_{2}$ protons appeared as a singlet at $\delta \approx 4.20$. A downfield shift was observed in the spectra of the complexes (for instance, $\delta 7.57$ for complex II) indicating the coordination of the $\mathrm{NH}_{2}$ nitrogen to platinum ion [15-17]. The spectra of all the complexes showed a singlet at $\approx \delta 9.00 \mathrm{ppm}$ due to the $\mathrm{NH}$ proton, suggesting a neutral nature of the ligand [10]. The signal of the NH proton was much less affected when compared to the group $\mathrm{NH}_{2}$ protons excluding the participation this group in the coordination [10]. The resonances related to the aromatic protons are not affected by addition of the metal ion and this pattern confirms that binding occurs in the $\mathrm{NH}_{2}$ group. The complexes were also characterized by ${ }^{195} \mathrm{Pt}$ NMR spectroscopy. ${ }^{195} \mathrm{Pt}$ chemical shifts are sensitive to the nature of the ligands and are a useful tool to predict the metal coordination sphere. In the ${ }^{195} \mathrm{Pt}$ NMR spectra signals were observed around $\delta-2220$ for complexes I, III and IV [30-32]. These chemical shift values are in accordance with the coordination sphere proposed. On the other hand, in the ${ }^{195} \mathrm{Pt}$ NMR spectra of complexes V-VIII were observed signals around $\delta-3200$. This is in accordance with upfield shift normally observed when chloride is substituted by iodide in $\mathrm{Pt}(\mathrm{II})$ complexes, since this ion is a better donor then the previous one [33].

\subsection{Molecular modeling}

Theoretical studies were performed to determine the more stable (cis or trans) molecular structure of the complexes [Pt(3$\left.\mathrm{MH})_{2} \mathrm{Cl}_{2}\right],\left[\mathbf{P t}(\mathbf{B C})_{2} \mathbf{C l}_{2}\right]$ and $\left[\mathrm{Pt}\left(4-\mathrm{MC}_{2} \mathrm{Cl}_{2}\right]\right.$. In these analyses the solvent and relativistic effects were taken into account due to the small energy differences between these conformations and the importance of these effects for the theoretical prediction of the electronic properties of these transition metal complexes [34]. Previous studies have shown that the B3LYP methodology employed in this work has been able to provide very good geometry for the platinum complexes with error lower than 5\% [35-37]. The optimized structures of cis-conformers of $\left[\mathrm{Pt}(3-\mathrm{MH})_{2} \mathrm{Cl}_{2}\right]$, $\left[\mathbf{P t}(\mathbf{B C})_{2} \mathbf{C l}_{2}\right]$ and $\left[\mathrm{Pt}\left(4-\mathrm{MC}_{2} \mathrm{Cl}_{2}\right]\right.$ complexes are shown in Fig. 3. The B3LYP optimized bond lengths and bond angles of the cisplatinum(II) complexes are collected in Table 3.

Overall, the results indicate that the coordination sphere of the complex around metal center is a distorted square-planar. The molecular distortion of platinum(II) complexes can be visualized by the bite $\mathrm{Cl}-\mathrm{Pt}-\mathrm{Cl}$ and $\mathrm{N}-\mathrm{Pt}-\mathrm{N}$ angles, which are computed to be around $95^{\circ}$ and $98^{\circ}$, respectively. These results have been previously observed in other platinum complexes, in which distinct dxz and dyz orbital interactions has been observed with ligand orbitals, thus providing different bite angles [34-37]. In general a rather small difference can be observed between results of the bond lengths and bond angles involving the metal center in the platinum complexes, comparing the complexes to each other. The Pt-N and $\mathrm{Pt}-\mathrm{Cl}$ bond lengths are computed to be around of 2.34 and $2.10 \AA$, respectively. It is important to note that the results in parentheses in Table 3 are the differences observed in the geometry of the obtained complexes in the PCM optimization. As can be seen, small differences were found as environmental effects are taken into account, being the major effect visualized in the energy of these structures. As it can be seen in the Fig. 3, the hydrogen interactions are observed between the two ligands in the cis optimized structures, favoring the stabilizing thermodynamical process. A only exception seems to be observed for cis- $\left[\mathrm{Pt}(3-\mathrm{MH})_{2} \mathrm{Cl}_{2}\right]$ complex. The $\mathrm{H}-\mathrm{O}$ hydrogen interactions observed in all complexes are in 

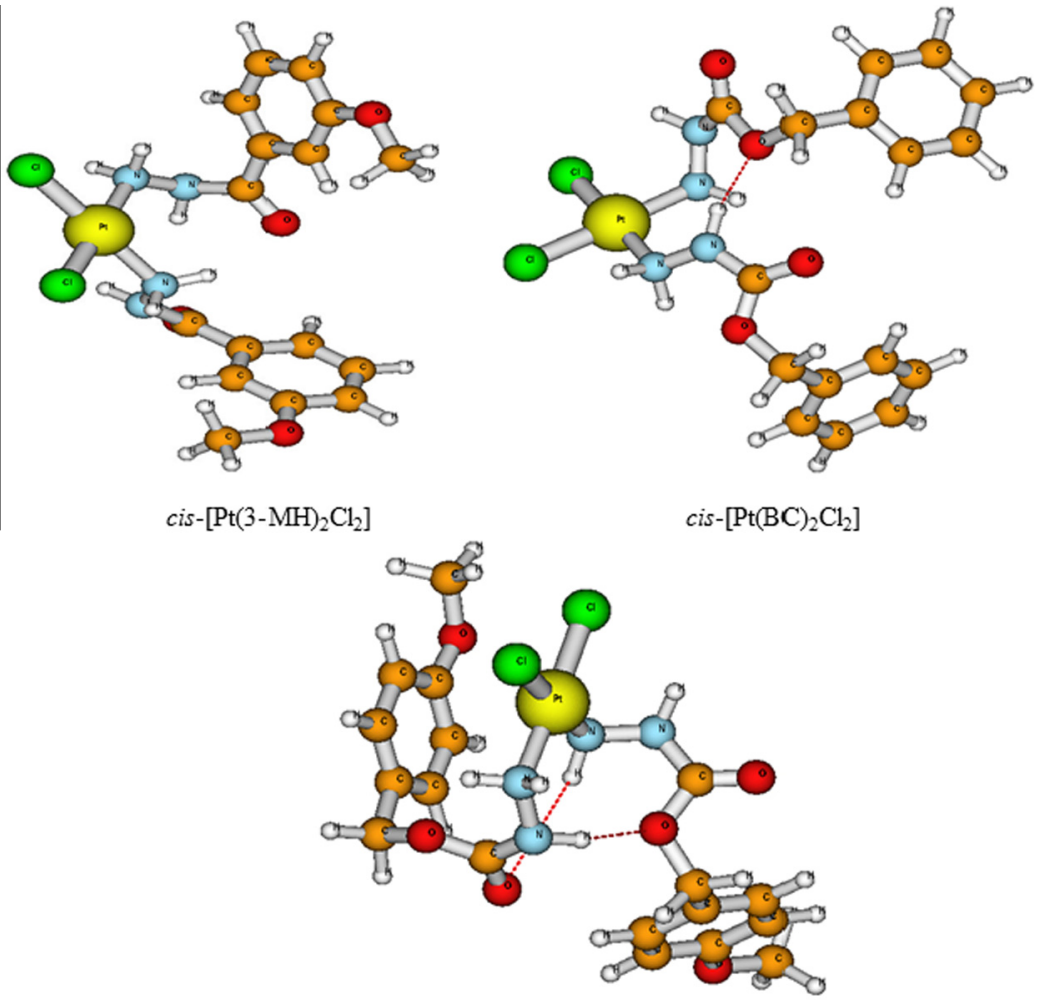

cis- $\left[\mathrm{Pt}(4-\mathrm{MC})_{2} \mathrm{Cl}_{2}\right]$

Fig. 3. Optimized geometry of the complexes.

Table 3

The B3LYP/SDD optimized bond lengths and bond angles of cis platinum complexes.

\begin{tabular}{|c|c|c|c|c|}
\hline Compounds & Parameters & $\begin{array}{l}\text { Bond } \\
\text { lengths }(\AA)\end{array}$ & Parameters & $\begin{array}{l}\text { Bond angles } \\
\text { (degrees) }\end{array}$ \\
\hline \multirow{8}{*}[\mathrm{Pt}(3-\mathrm{MH})_{2}]{$\mathrm{Cl}_{2}$} & $\mathrm{Pt}-\mathrm{Cl}$ & $2.338(34)$ & $\mathrm{Cl}-\mathrm{Pt}-\mathrm{Cl}$ & 95.64 \\
\hline & Pt-N & $2.125(12)$ & $\mathrm{N}-\mathrm{Pt}-\mathrm{N}$ & 98.206 \\
\hline & $\mathrm{N}-\mathrm{N}$ & $1.432(49)$ & Pt-N-N & $114.69(83)$ \\
\hline & $\mathrm{N}-\mathrm{C}$ & $1.397(412)$ & $\mathrm{N}-\mathrm{N}-\mathrm{C}$ & $115.77(25)$ \\
\hline & $\mathrm{C}-\mathrm{O}$ & $1.218(14)$ & $\mathrm{N}-\mathrm{C}-\mathrm{O}$ & $119.36(44)$ \\
\hline & $\mathrm{C}-\mathrm{C}$ & $1.485(94)$ & $\mathrm{O}-\mathrm{C}-\mathrm{C}$ & $123.85(82)$ \\
\hline & $\mathrm{C}-\mathrm{O}$ & $1.358(54)$ & $\mathrm{C}-\mathrm{O}-\mathrm{C}$ & $118.79(68)$ \\
\hline & $\mathrm{O}-\mathrm{C}$ & $1.425(26)$ & & \\
\hline \multirow[t]{7}{*}[\mathrm{Pt}(\mathrm{BC})_{2}]{$\mathrm{Cl}_{2}$} & $\mathrm{Pt}-\mathrm{Cl}$ & $2.340(35)$ & $\mathrm{Cl}-\mathrm{Pt}-\mathrm{Cl}$ & 95.29 \\
\hline & Pt-N & $2.117(15)$ & $\mathrm{N}-\mathrm{Pt}-\mathrm{N}$ & 98.36 \\
\hline & $\mathrm{N}-\mathrm{N}$ & $1.421(41)$ & Pt-N-N & 118.8 \\
\hline & $\mathrm{N}-\mathrm{C}$ & $1.380(73)$ & $\mathrm{N}-\mathrm{N}-\mathrm{C}$ & 122.7 \\
\hline & $\mathrm{C}-\mathrm{O}$ & $1.210(01)$ & $\mathrm{N}-\mathrm{C}-\mathrm{O}$ & $110.77(75)$ \\
\hline & $\mathrm{C}-\mathrm{O}$ & $1.346(63)$ & $\mathrm{C}-\mathrm{O}-\mathrm{C}$ & $116.84(48)$ \\
\hline & $\mathrm{O}-\mathrm{C}$ & $1.478(66)$ & $\mathrm{O}-\mathrm{C}-\mathrm{C}$ & 111.33 \\
\hline \multirow[t]{11}{*}[\mathrm{Pt}(4-\mathrm{MC})_{2}]{$\mathrm{Cl}_{2}$} & $\mathrm{Pt}-\mathrm{Cl}$ & $2.341(52)$ & $\mathrm{Cl}-\mathrm{Pt}-\mathrm{Cl}$ & 95.76 \\
\hline & Pt-N & $2.107(10)$ & $\mathrm{N}-\mathrm{Pt}-\mathrm{N}$ & 98.35 \\
\hline & $\mathrm{N}-\mathrm{N}$ & 1.467(39) & $\mathrm{Pt}-\mathrm{N}-\mathrm{N}$ & 115.72 \\
\hline & $\mathrm{N}-\mathrm{C}$ & $1.380(88)$ & & 121.1 \\
\hline & $\mathrm{C}-\mathrm{O}$ & $1.362(43)$ & $\mathrm{N}-\mathrm{N}-\mathrm{C}$ & 119.74 \\
\hline & $\mathrm{O}-\mathrm{C}$ & $1.476(77)$ & & 117.72 \\
\hline & $\mathrm{C}-\mathrm{C}$ & $1.498(500)$ & $\mathrm{N}-\mathrm{C}-\mathrm{O}$ & 111.06 \\
\hline & $\mathrm{C}-\mathrm{O}$ & $1.359(54)$ & & 110.85 \\
\hline & $\mathrm{O}-\mathrm{C}$ & $1.429(22)$ & $\mathrm{O}--\mathrm{C}-\mathrm{C}$ & 111.43 \\
\hline & & & & 109.52 \\
\hline & & & $\mathrm{C}-\mathrm{O}-\mathrm{C}$ & 118.63(65) \\
\hline
\end{tabular}

the range of $1.132-1.423 \AA$. In cis-[Pt $\left.(3-\mathrm{MH})_{2} \mathrm{Cl}_{2}\right]$ complex, this value is $1.452 \AA$, showing only a slightly weaker hydrogenation interaction.
Table 4

The B3LYP cis-trans energy differences $(\Delta \mathrm{E})^{*}$ in $\mathrm{kcal} \mathrm{mol}^{-1}$ of platinum complexes.

\begin{tabular}{llll}
\hline Complexes & Gas-phase & Solvent effect & Relativistic corrections \\
\hline$\left[\mathbf{P t}(\mathbf{3}-\mathbf{M H})_{\mathbf{2}}\right] \mathbf{C l}_{\mathbf{2}}$ & -9.35 & 2.34 & 6.43 \\
{$\left[\mathbf{P t}(\mathbf{B C})_{\mathbf{2}}\right] \mathbf{C l}_{\mathbf{2}}$} & -8.45 & 3.29 & 8.01 \\
{$\left[\mathbf{P t}(\mathbf{4}-\mathbf{M C})_{\mathbf{2}}\right] \mathbf{C l}_{\mathbf{2}}$} & -9.34 & 2.78 & 8.62 \\
\hline
\end{tabular}

${ }^{*} \Delta \mathrm{E}=\mathrm{E}_{\text {trans }}-\mathrm{E}_{\text {cis. }}$.

The energy results of the cis-trans conformations are shown in Table 4. As shown there, the trans-structures show to be thermodynamically more stable in the gas-phase. These results may be ascribed to big size of ligands in the platinum(II) complexes, which provides a high steric effect in the cis-conformation. The optimizations of platinum complexes were also performed by using PCM method. As can be seen in Table 4, the solvent effects change pronouncedly the energy differences, leading the cis-structure to be thermodynamically more stable than trans-conformers. In addition, the scalar relativistic corrections increase even more these energy differences, favoring the stabilization of cis-complexes. These results are in agreement with previous studies for platinum complexes, where relativistic effects showed to be of major importance to describe the electronic properties of these systems [34].

Thus, considering the spectroscopic and theoretical data, a distorted cis-square planar structure with carbazates or hydrazides coordinated via the $\mathrm{NH}_{2}$ groups were proposed for these compounds. The same coordination mode was observed in previous works for some complexes containing hydrazides as ligands $[38,39]$. 
Table 5

Cytotoxic activities against cell lines. $\mathrm{IC}_{50}(\mu \mathrm{M} \pm \mathrm{SD})$ and $\mathrm{SI}$.

\begin{tabular}{|c|c|c|c|}
\hline Compound & Tumor cells $\mathrm{IC}_{50}(\mu \mathrm{M} \pm \mathrm{SD})^{\mathrm{a}}$ & Non-tumor cells $\mathrm{IC}_{50}(\mu \mathrm{M} \pm \mathrm{SD})^{\mathrm{a}}$ & $\mathrm{SI}^{\mathrm{b}}$ \\
\hline 4-MC & $38.0 \pm 3.8$ & - & - \\
\hline$\left[\mathrm{Pt}(4-\mathrm{MC})_{2} \mathrm{Cl}_{2}\right]$ or I & $32.0 \pm 3.2$ & $19.7 \pm 1.26$ & 0.6 \\
\hline $\mathrm{BC}$ & $>100$ & - & - \\
\hline$\left[\mathrm{Pt}(\mathrm{BC})_{2} \mathrm{Cl}_{2}\right]$ or II & $25.5 \pm 2.5$ & $8.9 \pm 0.63$ & 0.3 \\
\hline $4-\mathrm{FH}$ & $>100$ & - & - \\
\hline$\left[\mathrm{Pt}(4-\mathrm{FH})_{2} \mathrm{Cl}_{2}\right]$ or III & $7.0 \pm 0.7$ & $12.2 \pm 0.62$ & 1.7 \\
\hline Carboplatin & $10.0 \pm 1.2$ & - & - \\
\hline Cisplatin & $1.1 \pm 0.1$ & $16.5 \pm 2.4$ & 15.0 \\
\hline
\end{tabular}

Data show means \pm SD of three independent experiments.

${ }^{a} \mathrm{IC}_{50}$ is the concentration required to inhibit $50 \%$ of cell growth.

b SI - selectivity index.

\section{Biological studies}

\subsection{Anti-M. tuberculosis activity}

All complexes were evaluated against $M$. Tuberculosis. The minimum inhibitory concentration (MIC) values for the complexes and organic compounds were higher than $25 \mu \mathrm{g} / \mathrm{mL}$, which means that they are not very active $[40,41]$.

\subsection{Cytotoxic studies}

Complexes I-III were selected for studies of cytotoxic activity against K562 tumor cells (human leukemia cells) and health cell line from mouse (L929) and the obtained $\mathrm{IC}_{50}$ values are depicted in Table 5 . $\mathrm{IC}_{50}$ values obtained for two platinum complexes used in chemotherapy, cisplatin and carboplatin, are also shown for the sake of comparison. The results showed that activity of the complexes on K562 cells are higher than the correspondent free ligands, and follows the order $[\mathbf{P t}(4-$ $\left.\mathbf{F H})_{2} \mathbf{C l}_{2}\right]>\left[\mathbf{P t}(\mathbf{B C})_{2} \mathbf{C l}_{2}\right]>\left[\mathbf{P t}\left(4-\mathbf{M C}_{2} \mathbf{C l}_{2}\right]\right.$. Complex III shows the strongest ability to inhibit the growth of chronic myelogenous leukemia cell line being more active than carboplatin. In addition, the platinum complexes with 4-methoxybenzylcarbazate (4-MC) and benzyl carbazate (BC) also exhibited good activity against $\mathrm{K} 562$ cell line. However, all complexes showed a low selectivity index in K562 cells and as can be seen in Table 5, were less active than cisplatin.

\section{Concluding remarks}

Several carbazates or hydrazides Pt(II) complexes were synthesized and characterized using spectroscopic and spectrometric techniques. In all reactions, the ligands have shown monodentate behavior forming complexes of general formula cis- $\left[\mathrm{Pt}(\mathrm{L})_{2} \mathrm{Cl}_{2}\right]$. A distorted cis-square planar structure with carbazates or hydrazides coordinated via the $\mathrm{NH}_{2}$ groups has been proposed for these compounds. Theoretical data show good agreement with the experimental results. The cytotoxicity of the ligands $\mathrm{FH}, \mathrm{BC}$ and $\mathrm{MC}$, and their complexes with chlorine, were examined on K562 tumor cells and health cell line from mouse (L929). Complexes are more effective than the respective free ligands, displaying good cytotoxicity. On the contrary, the microbiological assays against M. tuberculosis showed that all the tested complexes exhibited low cytotoxicity.

\section{Acknowledgements}

We acknowledge CNPq (Conselho Nacional de Desenvolvimento Científico e Tecnológico, Brazil), RMQ (Rede Mineira de Química, Brazil), FAPEMIG (Fundação de Amparo à Pesquisa de Minas Gerais, Brazil), and INCT-Catálise by financial support and fellowships. The authors also are thankful to the Grupo de Materiais Inorgânicos do Triângulo - GMIT research group supported by FAPEMIG (APQ-00330-14).

\section{References}

[1] S. Rollas, S..G. Küçükgüzel, Molecules 12 (2007) 1910-1939.

[2] B. Singh, R. Srivastava, K.K. Narang, Synth. React. Inorg. Met. Org. Chem. 30 (2000) 1175-1192.

[3] V. Judge, B. Narasimhan, M. Ahuja, Med. Chem. Res. 21 (2012) 3940-3957.

[4] J. Cymerman-Craig, D. Willis, S.P. Rubbo, S. Edgar, Nature 176 (1995) 34.

[5] R. Malhotra, S. Kumar, K.S. Dhindsa, Indian J. Chem. 32A (1993) 5457.

[6] Z. Muhi-Eldeen, K. Al-Obaidi, M. Nadir, F. Rochev, Eur. J. Med. Chem. 27 (1992) 101.

[7] J. Martinez, A. Martinez, M.L. Cuenca, A.D. Lopez, Synth. React. Inorg. Met.-Org. Chem. 18 (1988) 881.

[8] M.G. ElWahed, A.M. Hassan, H.A. Hammad, M.M. El Desoky, Bull. Korean Chem. Soc. 13 (1992) 113-116.

[9] A.P.S. Fontes, W. Guerra, F.C. Machado, M.V. de Almeida, W.A. Alves, A.M.D.C. Ferreira, A. Paduan-Filho, Transition Met. Chem. 29 (2004) 382.

[10] V. Mahalingam, N. Chitrapriya, M. Zeller, K. Natarajan, Polyhedron 28 (2009) 1532.

[11] E.H.S. Sousa, F.G.M. Vieira, J.S. Butler, L.A. Basso, D.S. Santiago, I.C.N. Diógenes, L.G.F. Lopes, P.J. Sadler, J. Inorg. Biochem. 140 (2014) 236-244.

[12] E.H.S. Sousa, L.A. Basso, D.S. Santos, I.C.N. Diógenes, E. Longhinotti, L.G.F. Lopes, I.S. Moreira, J. Biol. Inorg. Chem. 17 (2012) 275-283.

[13] P. Sur, S.P. Chatterjee, P. Roy, B. Sur, Cancer Lett. 94 (1995) 27.

[14] P.P. Silva, W. Guerra, G.C. dos Santos, N.G. Fernandes, J.N. Silveira, A.M. da Costa Ferreira, T. Bortolotto, H. Terenzi, A.J. Bortoluzzi, A. Neves, E.C. PereiraMaia, J. Inorg. Biochem. 132 (2014) 67.

[15] G.D. de Souza, M.A. Rodrigues, L.E. Fernandes, P.P. Silva, R. Ruggiero, E.C. Pereira-Maia, W. Guerra, W. Cent, Eur. J. Chem. 11 (2013) 290.

[16] N. Dodoff, K. Granharov, N. Spassovska, J. Inorg. Biochem. 60 (1995) 257.

[17] N. Dodoff, K. Granharov, R. Gugova, N. Spassovska, J. Inorg. Biochem. 54 (1994) 221.

[18] J.C. de Jong, L.G. Sørensen, H. Tornqvist, P. Jacobsena, Bioorg. Med. Chem. Lett. 14 (2004) 1741.

[19] M.A. Dekeyser, P.T. McDonald, G.W. Angle, Chimia 57 (2003) 702.

[20] M. Milenković, A. Bacchi, G. Cantoni, S. Radulovićc, N. Gligorijević, S Aranđelović, Dušan Sladić, Miroslava Vujčić, Dragana Mitić, Katarina Anđelković, Inorg. Chim. Acta 395 (2013) 33.

[21] (a) A.D. Becke, Phys. Rev. A 38 (1988) 3098-3100; (b) A.D. Becke, J. Chem. Phys. 98 (1993) 5648-5652.

[22] C. Lee, W. Yang, R.G. Parr, Phys. Rev. 37B (1988) 785.

[23] M. Dolg, in: J. Grotendorst (Ed.), Modern Methods and Algorithms of Quantum Chemistry, vol. 1, John von Neumann Institute for Computing, Julich, Germany, 2000, pp. 479-508.

[24] J.A. Pople, M. Head-Gordon, K.J. Raghavachari, Chem. Phys. 87 (1987) 5968

[25] X.S. Li, M.J.J. Frisch, Chem. Theory Comput. 2 (2006) 835.

[26] J.C. Palomino, A. Martin, M. Camacho, H. Guerra, J. Swings, F. Portaela Antimicrob. Agents Chemother. 46 (2002) 2720-2722.

[27] W. Geary, J. Coord. Chem. Rev. 7 (1971) 81.

[28] Q. Ul Ain, U. Ashiq, R.A. Jamal, M. Mahrooof-Tahir, Spectrochim. Acta, Part A 115 (2013) 683.

[29] K. Nakamoto, Infrared, Raman Spectra of Inorganic and Coordination Compounds, 5th ed., Wiley, New York, 1997.

[30] M. Wenzel, E. Bigaeva, P. Richard, P. Le Gendre, M. Picquet, A. Casini, E. Bodio, J Inorg. Biochem. 141 (2014) 10-16.

[31] E.T. Cesar, R.N. Berg, A.P.S. Fontes, H. Silva, M.F. Saraiva, W. Guerra, M.V. de Almeida, Bull. Korean Chem. Soc. 28 (2007) 295.

32] W. Guerra, M.V. de Almeida, H. Silva, A.P.S. Fontes, Quím. Nova 28 (2005) 809.

[33] T.T. Tavares, G.F. Teixeira, C.M. Lopes, W.T.G. Novato, H. Silva, M.T.P. Lopez, M.V. de Almeida, R.M. Grazul, H.F. dos Santos, A.P.S. Fontes, J. Inorg. Biochem. 115 (2012) 13. 
[34] M. Amati, S. Belviso, P.L. Cristinziano, C. Minichino, F. Lelj, I. Aiello, M. La Deda, M. Ghedini, J. Phys. Chem. A 111 (2007) 13403.

[35] M. Hashemi, J. Organometall. Chem. 776 (2015) 77-82.

[36] K. Yunus, V.T. Yilmaz, Struct. Chem. 25 (2014) 231-238.

[37] W.A. Lai, J.N. Yao, S. Shaik, H. Chen, J. Chem. Theor. Computat. 8 (2012) 2991 2996.

[38] D. Kushev, G. Gorneva, S. Taxirov, N. Spassovska, K. Grancharov, Biol. Chem. 380 (2005) 1287-1294.
[39] G.D. Souza, M.A. Rodrigues, P.P. Silva, E.C. Pereira-Maia, F.V. Botelho, T.A. Campos, E.F. Franca, K.J. Almeida, W. Guerra, Croat. Chem. Acta 86 (2013) 201206.

[40] M. Mondelli, F. Pavan, P.C. de Souza, C.Q. Leite, J. Ellena, O.R. Nascimento, G. Facchin, M.H. Torre, J. Mol. Struct. 1036 (2013) 180.

[41] J.C. Almeida, I.M. Marzano, F.C. Silva de Paula, M. Pivatto, N.P. Lopes, P.C. de Souza, F.R. Pavan, A.L.B. Formiga, E.C. Pereira-Maia, W. Guerra, J. Mol. Struct. 1075 (2014) 370. 